\title{
The current state of the introduction coenopopulation of Gymnospermium odessanum on the botanical-geographical plot "Steppes of Ukraine" at the M. M. Gryshko National Botanical Garden of the NAS of Ukraine
}

\author{
(ㄱ) Victoria Gritsenko
}

M.M. Gryshko National Botanical Garden, National Academy of Sciences of Ukraine, Tymiryazevska str. 1, 01014 Kyiv, Ukraine; gritsenkoviktoria@gmail.com

Received: 06.12.2021 | Accepted: 23.12.2021 | Published online: 14.01.2022

\begin{abstract}
Gymnospermium odessanum is a rare relict endemic plant species. The research was carried out during G. odessanum flowering in 2019-2021 at the botanical-geographical plot "Steppes of Ukraine" of the M.M. Gryshko National Botanical Garden, National Academy of Sciences of Ukraine (NBG). Ecological and coenotic conditions of introduction at the NBG differ from natural habitats of the species and are not optimal for its vegetation. However, this species demonstrated ecological-coenotic plasticity and, over the decades, has formed a stable homeostatic introduction coenopopulation here. As of 2021, the area of introduction coenopopulation of G. odessanum at the NBG was 2,075 $\mathrm{m}^{2}$. It comprises 412 individuals of this species (including 40 seedlings, 241 juvenile, 45 immature, 40 virginal, 45 generative, and 1 subsenile plants). Coenopopulation fragments with a high density of $G$. odessanum individuals are rare here, so the average density is low - only 0.2 individuals per $1 \mathrm{~m}^{2}$. In 2021, in the spectrum of age states, the total percentage of pregenerative individuals was very high and reached $88.8 \%$; the share of generative individuals was $10.9 \%$.

In general, the age structure of the introduction coenopopulation of G. odessanum is characterized by long-term (2010-2021) stability. The spatial distribution of individuals in the introduction coenopopulation is of two kinds - random and in groups. This is due to combined myrmecochoric and barochoric propagation. Also due to myrmecochory, this coenopopulation tends to spread the area. Compared to natural coenopopulations, the introduction coenopopulation of G. odessanum at the NBG is characterized by a larger area, a much significant number, and, at the same time, a low average density of individuals. However, like in most of natural populations, its age spectrum is left-sided.

The conducted research testifies the successful formation of the introduction coenopopulation of G. odessanum in the meadow-steppe cultural phytocoenosis of the NBG. This introduction coenopopulation is an example of a successful multi-year scientific experiment and effective ex situ protection and preservation of $G$. odessanum on the northern border of the Right Bank Forest-Steppe of Ukraine, far beyond the natural range of this endemic plant species.
\end{abstract}

Funding: The work has been realized within the following research program of the Department of Natural Flora Department of the M.M. Gryshko National Botanical Garden, National Academy of Sciences of Ukraine 2020-2024 "Botanical and geographical principles of protection of floristic diversity and the formation of the introduction populations of plants" (state registration number 0120U000174).

Competing Interests: The author declares no conflict of interest. 


\section{Introduction}

Gymnospermium Spach (Berberidaceae Juss.) is a small genus (7-12 species) of early flowering tuberous herbs, distributed from east China to the Balkans (Rosati et al., 2018). Gymnospermium odessanum (DC.) Takht. is a relict endemic species with a narrow disjunctive distribution range (Scherbakova \& Novosad, 2018). It is listed as a vulnerable species in the Red Book of Ukraine (Kritska \& Novosad, 2009) and also protected by the Red Book of the Republic of Moldova (Kolomiychuk \& Popova, 2018). This species is distributed in Dobrogea region of Moldova and NorthWestern part of the Black Sea region of Ukraine (Kritska \& Novosad, 2009; Scherbakova \& Novosad, 2018). It is also reported as a phytorarity for the Steppe zone of Ukraine (Sobko et al., 2013).

As a result of phylogenetic analyzes, it was found that $G$. odessanum is sister to G. peloponnesiacum (Phitos) Strid from South Greece. Both species are, in turn, sister to G. altaicum (Pallas) Spach (Barina et al., 2017; Rosati et al., 2018). However, despite small number of representatives, the taxonomy of the genus is not fully clear and wellestablished yet. In particularly, recently Rosati et al. (2018) discribed a new subspecies of the genus (G. scipetarum Paparisto \& Qosja ex E. Mayer \& Pulevic subsp. eddae Rosati, Farris, Fascetti \& Selvi) for the flora of Italy.

In Ukraine, G. odessanum has been extensively investigated in the nature (Visjulina, 1953; Litvinenko, 1986, 2010; Melnyk, 1994, 2000; Scherbakova, 2005, 2008, 2010, 2011; Kritska \& Novosad, 2009; Litvinenko \& Shcherbakova, 2009; Kritska, 2012; Scherbakova \& Barmak, 2013; Smetana et al., 2014; Trotner, 2016, 2017). This species has also been studied in Dobrogea (Doroftei \& Mierla, 2007) and Moldova, in general (Izverskaya et al., 2013, 2017). In particular, is interesting that Izverskaya et al. (2017) predicted displacement of G. odessanum in the Dniester river basin in Moldova to the north due to climate change.

Scherbakova \& Novosad comprehensively investigated the distribution, ecological and coenotic peculiarities, and some aspects of $\mathrm{G}$. odessanum protection. After that, additional information about the distribution and ecology of G. odessanum in
Ukraine was provided by Krasova et al. (2019), Ponomareva et al. (2019), and Shiryaeva et al. (2019, 2020).

Krasova et al. (2016) introduced G. odessanum on the dump of the mining quarry to restore phytodiversity in the anthropogenic landscapes of Kryvbas, which were decommissioned. Pavlenko et al. (2020), during a survey of post-mining quarry and dump complexes in the area of Kryvyi Rih, found that G. odessanum is naturalized here as a result of reclamation.

Gymnospermium odessanum is an ornamental spring ephemeroid growing and ex situ protected in several botanical gardens of Ukraine (Mashkovska, 2015; Scherbakova \& Novosad, 2018). Namely, it is cultivated at the M.M. Gryshko National Botanical Garden, National Academy of Sciences of Ukraine (NBG); Donetsk Botanical Garden, National Academy of Sciences of Ukraine (Krokhmal \& Netsvetov, 2015); Botanical Garden of Kherson State University; Botanical Garden of V.N. Karazin National University of Kharkiv; Botanical Garden of I.I. Mechnikov National University of Odesa (Yermolaieva, 2010); Botanical Garden of Ivan Franko National University of Lviv; Kryvyi Rih Botanical Garden, National Academy of Sciences of Ukraine (Trotner, 2016; Krasova et al., 2019); O.V. Fomin Botanical Garden of Taras Shevchenko National University of Kyiv (Peregrym et al., 2014).

In the Department of Natural Flora of the NBG, G. odessanum was introduced and partially studied on the botanicalgeographical plots "Steppes of Ukraine" (Borodina, 1972, 1976) and "Forests of the plain part of Ukraine" (Melnyk, 1994), and the collection plot "Rare plants of the Ukrainian flora" (Sobko \& Borodina, 1987; Sobko \& Gaponenko, 1996). It was found that $G$. odessanum formed a stable homeostatic introduction coenopopulation on the botanical-geographical plot "Steppes of Ukraine" of the NBG (Gritsenko, 2009). Previously, only brief information on this introduction coenopopulation was known (Gritsenko, 2010, 2012, 2014, 2017a, 2019a, b; Gritsenko et al., 2017). Thus, there was a need for a more detailed and in-depth study of this introduction coenopopulation.

In 2021, the phenology of G. odessanum was studied on the botanical-geographical plot 
"Steppes of Ukraine" of the NBG (Gritsenko, 2021). Gymnospermium odessanum grows here outside its natural range (far to the north). The introduction conditions at the NBG, which is located on the northern border of the Right Bank Forest-Steppe of Ukraine, significantly differ from those in the natural habitats of the species in the North-Western Black Sea region.

There are two specific directions of plant introduction - within and outside the natural range, both of which are strongly argued (Gaponenko \& Gnatiuk, 2016) and can be successfully realized. In recent years, in both of dirrections, the experimental studies of introduction populations of different rare plant species were conducted at the Department of Natural Flora of the NBG (Melnyk et al., 2018; Gritsenko, 2020). In particular, it was found that the introduction coenopopulation of the rare early-spring ephemeroid Crocus reticulatus Steven ex Adam at the NBG (which is, by the way, located within the species' natural range) was in the phase of logistic growth in 2020. This confirmed the success of the introductory experiment (Gritsenko, 2020).

Hence, it was worthing to find out whether the introduction of $\mathrm{G}$. odessanum has been also fruitful. We suggested this an example of successful multi-decade scientific experiment, and effective ex situ protection and preservation of $G$. odessanum on the northern border of the Right-Bank Forest-Steppe of Ukraine.

\section{Material and methods}

The studies were conducted during the time of G. odessanum flowering in 2019-2021 at the botanical-geographical plot "Steppes of Ukraine" of the NBG. Gymnospermium odessanum was introduced here from the natural habitats of Odessa surroundings in 1953 and, repeatedly, in 1964 (Borodina, 1972). These initial individuals served as a base to form the introduction coenopopulation of G. odessanum. Additional solitary individuals were collected in 2002 and 2010 (Gritsenko et al., 2017) and planted in the nursery - they did not participate in the formation of the main introduction coenopopulation of the species.
In this article, for coenopopulation description, author applies the term 'introduction' ('інтродукційна' in Ukrainian) instead of 'introduced' ('інтродукована' in Ukrainian), because it reflects the semantic meaning much more correctly.

The area of the introduction coenopopulation of G. odessanum was calculated with a precision of $1 \mathrm{~m}^{2}$. The area's configuration was plotted on the satellite images of Google Maps (2021). According to standard methodology, phenomenological observations of G. odessanum were performed daily during its mass flowering (Beideman, 1974; Zaitsev, 1978). The plants were not excavated or damaged during the research; only aboveground parts were considered. The age states of G. odessanum were determined according to Litvinenko (2010). In general, the number of generative individuals (total amount of young, middle-aged, and old generative plants) was counted. The study of the coenopopulation structure was conducted according to Uranov (1976). The average density of individuals per $1 \mathrm{~m}^{2}$ was determined as the individuals' number divided by the total area. When mapping the spatial location of generative individuals, the total area of the coenopopulation was subdivided into smaller $5 \times 5 \mathrm{~m}$ plots, using cords and measuring tape. Deviations between two numerical data were calculated by the formulae: Dev. $=100-y \times 100 / x$, where ' $x$ ' is the first datum, and ' $y$ ' is the second one.

Plant names were verified and provided according to Euro+Med PlantBase (2021) nomenclature. Species were determined following Prokudin (1987). All photos were captured by the author using a Canon Power Shot SD 4000 IS digital ELPH camera.

\section{Results and discussion}

\section{Area of the introduction coenopopulation}

From a landscape perspective, the botanicalgeographical plot "Steppes of Ukraine" is an extensive glade covering 2.5 hectares and surrounded by forest vegetation (Fig. $1 \mathrm{~A}$ ). The introduction coenopopulation of G. odessanum is located in the western part of this plot on the open area with a flat relief (Fig. $1 \mathrm{~A}-\mathrm{C}$ ). The coordinates inside of G. odessanum coenopopulation are following - N $50.412000^{\circ}$, 

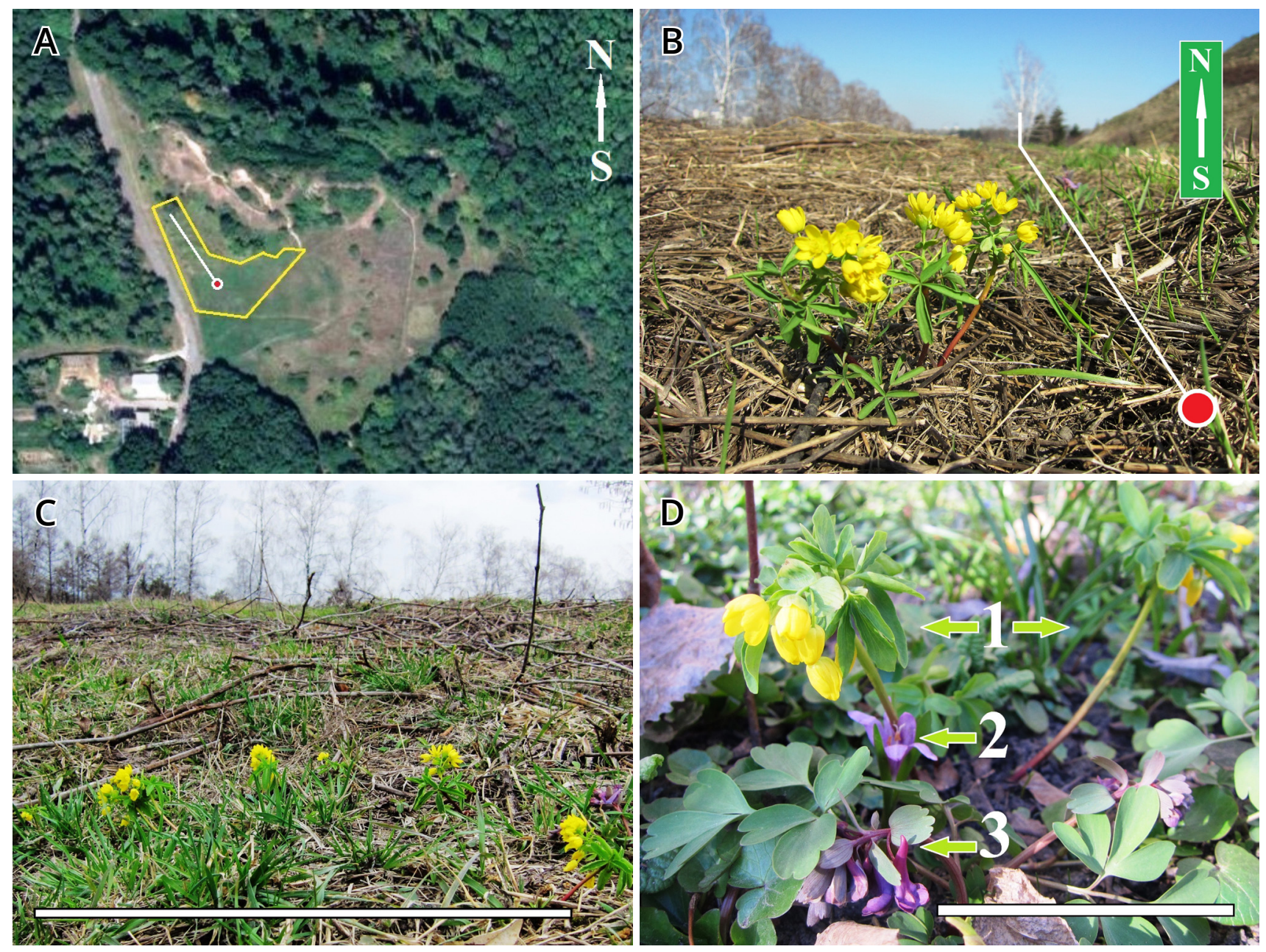

Figure 1. The introduction coenopopulation of Gymnospermium odessanum on the botanical-geographical plot "Steppes of Ukraine" at the M. M. Gryshko National Botanical Garden of the NAS of Ukraine: A - location and configuration (source: Google Maps; the yellow line indicates the boundaries of the coenopopulation; the red point indicates the coordinates inside of the coenopopulation); B - the fragment (the red point corresponds to A); $\mathbf{C}$ - the projective cover of the grass during the flowering time of G. odessanum and the beginning of vegetation of cereals; $D$ - the fragment of spring synusia with the participation of G. odessanum (1), Colchicum bulbocodium subsp. versicolor (2) and Corydalis solida (3). Scales: A-B - 50 m; C - $0.5 \mathrm{~m} ; \mathrm{D}-0.1 \mathrm{~m}$.

E $30.565062^{\circ}$. The coenopopulation has polygonal (decagonal) outlines and area of $2075 \mathrm{~m}^{2}$ (over $0.2 \mathrm{ha}$ ), bounded by earth roads (Fig. $1 \mathrm{~A})$.

Scherbakova \& Novosad (2018) generally characterized contemporary natural populations of G. odessanum as local and having small areas. Smetana et al. (2014) indicated that 27 natural populations of G. odessanum in the Ingulets river basin occupy areas from $0.5 \mathrm{~m}^{2}$ to $500 \mathrm{~m}^{2}$ and are confined to the slopes of the predominantly eastern exposure with $5-30^{\circ}$ inclination. Thus, the introduction coenopopulation of G. odessanum at the NBG, compared to natural ones, is characterized by significantly larger area and is scattered on the flat relief.

\section{Coenotic features}

Gymnospermium odessanum grows on the botanical-geographical plot "Steppes of Ukraine" in the composition of artificially created meadow-steppe phytocoenosis (Gritsenko, 2017b). During the flowering time of G. odessanum (March - beginning of April) the soil surface is covered with a loose litter from the remnants of various plants of the previous year (Fig. 1 B). The projective cover of the grass stand reaches $60 \%$ (Fig. $1 \mathrm{C}$ ). In some places, the projective cover of G. odessanum can be up to $10 \%$. The height of G. odessanum flowering shoots above the soil surface is 5-12 cm (Fig. $1 \mathrm{D}$ ).

In the natural coenopopulations of G. odessanum, the projective grass cover varies 
Table 1. Spring synusiae during the flowering of Gymnospermium odessanum on the botanical-geographical plot "Steppes of Ukraine" at the NBG in 2019-2021.

\begin{tabular}{|c|c|c|c|}
\hline $\mathrm{Nr}$ & Plant species & Group & Phenophase \\
\hline 1 & Achillea millefolium $\mathrm{L}$. & $\mathrm{N}$ & I \\
\hline 2 & Adonis vernalis $\mathrm{L}$. & In & III \\
\hline 3 & Adonis volgensis DC. & In & III \\
\hline 4 & Arrhenatherum elatius (L.) J. Presl \& C. Presl & A & I \\
\hline 5 & Bromopsis inermis (Leyss.) Holub & $\mathrm{N}$ & I \\
\hline 6 & Calamagrostis epigejos (L.) Roth & $\mathrm{N}$ & I \\
\hline 7 & Colchicum bulbocodium Ker Gawl. subsp. versicolor (Ker Gawl.) K. Perss. & In & VI \\
\hline 8 & Corydalis solida (L.) Clairv. & $\mathrm{N}$ & IV \\
\hline 9 & Dactylis glomerata L. & $\mathrm{N}$ & I \\
\hline 10 & Delphinium sergii Wissjul. & In & I \\
\hline 11 & Elytrigia intermedia (Host) Nevski & In & I \\
\hline 12 & Elytrigia repens (L.) Nevski & $\mathrm{N}$ & I \\
\hline 13 & Ficaria calthifolia Rchb. & In & IV \\
\hline 14 & Ficaria verna Huds. & $\mathrm{N}$ & IV \\
\hline 15 & Gagea liotardii (Sternb.) Schult. \& Schult. f. & $\mathrm{N}$ & IV \\
\hline 16 & Gagea minima (L.) Ker Gawl. & $\mathrm{N}$ & IV \\
\hline 17 & Gagea pusilla (F. W. Schmidt) Sweet & $\mathrm{N}$ & IV \\
\hline 18 & Gymnospermium odessanum (DC.) Takht. & In & $\mathrm{V}$ \\
\hline 19 & Muscari neglectum Guss. ex Ten. & In & III \\
\hline 20 & Ornithogalum boucheanum (Kunth) Asch. & In & I \\
\hline 21 & Ornithogalum fimbriatum Willd. & In & III \\
\hline 22 & Paeonia tenuifolia L. & In & I \\
\hline 23 & Papaver orientale L. & $\mathrm{A}$ & I \\
\hline 24 & Pulsatilla pratensis (L.) Mill. & In & III \\
\hline 25 & Ranunculus illyricus L. & In & I \\
\hline 26 & Scilla bifolia L. & $\mathrm{N}$ & IV \\
\hline 27 & Scilla siberica Haw. & In & III \\
\hline 28 & Tulipa biebersteiniana Schult. \& Schult. f. & In & I \\
\hline 29 & Veronica hederifolia L. & $\mathrm{N}$ & $\mathrm{V}$ \\
\hline 30 & Viola odorata L. & $\mathrm{N}$ & II \\
\hline
\end{tabular}

Note. Groups: N - native plant species; In - introduced plant species; A - alien plant species. Phenophases: I - beginning of vegetation; II - beginning of vegetation and budding; III - budding; IV - budding and beginning of flowering; $\mathrm{V}$ - mass flowering; $\mathrm{VI}$ - completion of flowering.

in a wide range from $20 \%$ to $95 \%$ (Smetana et al., 2014). Gymnospermium odessanum often dominates in the spring synusia (Scherbakova \& Novosad, 2018). Krasova et al. (2016) observed a projective cover of G. odessanum reaching 50-60\%. The height of G. odessanum in nature is $5-20 \mathrm{~cm}$ (Kritska \& Novosad, 2009) or 10-15 cm (Trotner, 2017).

In the species composition of the artificially created phytocoenosis (Table 1), introduced plant species represent $50.0 \%$ (15 species), native - $43.3 \%$ (13 species), alien - 6.7\% 


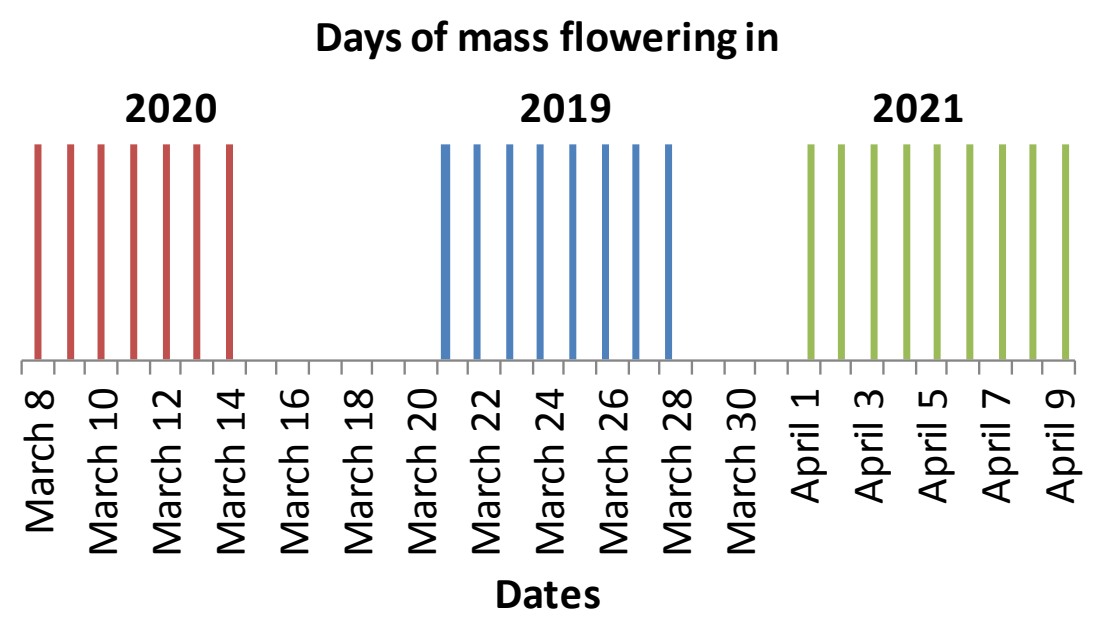

Figure 2. Dynamics of Gymnospermium odessanum mass flowering in the introduction coenopopulation at the NBG in 2019-2021.

(two species). At the same time, many plant species (13 species, $43.3 \%$ ) have not begun vegetation and therefore are not visible in the spring synusiae yet. In particular, cereals have just started their growth (Table 1; Fig. $1 \mathrm{C}$ ). From other hand, at this time, Colchicum bulbocodium Ker Gawl. subsp. versicolor (Ker Gawl.) K. Perss. already finishes its flowering (Table 1; Fig. 1 D). In this spring synusia, all plants are herbaceous (Table 1). Of course, such species composition of the spring synusia is possible only in introduction conditions and does not occur in natural phytocoenoses.

In Ukraine, the natural habitats of G. odessanum are located on the limestones, loess-limestones and granite slopes, ravines and gullies, in the phytocoenoses of shrub steppes, on the open areas of steppe slopes adjacent to shrubby thickets, and forest glades (Scherbakova, 2005; Kritska \& Novosad, 2009; Kritska, 2012). Smetana et al. (2014) indicated a wide range of coenotic conditions for the G. odessanum existence, particularly shrubby, steppe, and rocky vegetation. Solomakha (2015) noted that in the Ukrainian Northern Black Sea region, G. odessanum occurs in the forest and shrub communities. Scherbakova \& Novosad (2018) indicate that sylvatic communities (i.e., natural ravine forests, thickets of shrubs, and secondary forest phytocoenoses) are optimal for the existence of G. odessanum in Ukraine. In Moldova, this species occurs exclusively in light oak forests. It does not spread to open areas in Moldova, and therefore it is considered there a typical forest representative (Izverskaya et al., 2013).
Thus, the coenotic conditions of G. odessanum habitats under introduction on the botanical-geographical plot "Steppes of Ukraine" differ from those in nature. This confirms the opinion of Scherbakova \& Novosad (2018), who declared broad ecological and coenotic plasticity of G. odessanum in Ukraine.

\section{Phenology features during Gymnospermium odessanum flowering}

During the flowering of G. odessanum, the following phenophases were distinguished: the beginning of flowering, the mass flowering, and the completion of flowering. The mass flowering of G. odessanum in 2019 lasted eight days, in 2020 - seven days, in 2021 - nine days (Fig. 2). The earliest mass flowering occurred in March 2020, the latest - in early April 2021 (Fig. 2). The beginning of mass flowering in 2020 and 2021 differed significantly and resulted in 24 days of delay. This may be due to the significant differences in spring weather during these years. In 2021, the entire growing season of G. odessanum lasted from March 24 to May 22 and amounted to 60 days (Gritsenko, 2021). At the same time, mass flowering took up to $15 \%$ of the entire vegetation period.

The flowering of $G$. odessanum occured in March-April both in the conditions of introduction at the NBG, and in nature (Visjulina, 1953; Kritska \& Novosad, 2009; Trotner, 2017). During G. odessanum flowering, the composition of plant species in the spring synusia and phenophases of these plants were the same in 2019-2021 (Table 1). At different 

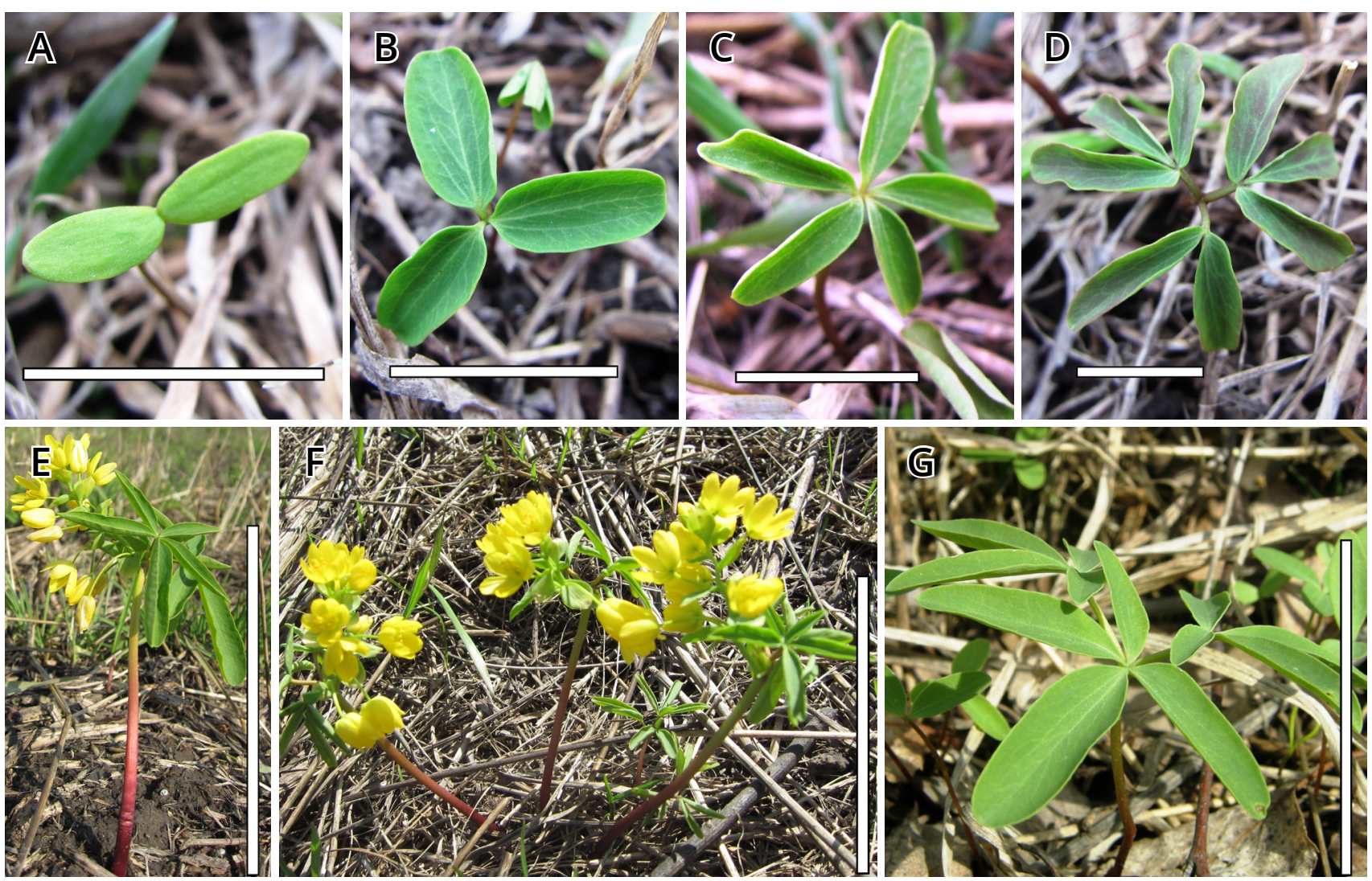

Figure 3. Gymnospermium odessanum individuals: A - seedling; B - juvenile plant; C - immature plant; D - virginal plant; E-F - a generative plant with one (E) and three (F) flowering shoots; $G$ - sub-senile plant. Scales: A-D - $2 \mathrm{~cm}$; E-G - $10 \mathrm{~cm}$.

dates of G. odessanum flowering, an associated shift of phenophases of other plant species in the spring synusia was observed. Therefore, the phenophases of these plants in different years were the same, too (Table 1).

Fruiting of G. odessanum in nature occurs from the middle of April to early May (Trotner, 2017). Ripening and dispersion of seeds of this species in the introduction conditions occur in May (Gritsenko, 2021). The seeds germinate in the spring of next year. Vegetative reproduction is not usual for G. odessanum (Litvinenko \& Shcherbakova, 2009; Scherbakova \& Barmak, 2013).

\section{Ontogenetic aspect}

Up to date, several generations of introduced G. odessanum were formed at the botanicalgeographical plot "Steppes of Ukraine". During G. odessanum flowering, seedlings, as well as juvenile, immature, virginal, generative, and sub-senile individuals were observed (Fig. 3). In the introduction conditions, the principal parameters of the aboveground plant parts of G. odessanum corresponded to those registered in nature (Litvinenko, 2010).
Among the generative individuals, the most frequent were those with one flowering shoot (Fig. 3 E; Table 2). However, plants with two or three flowering shoots occasionally occurred too (Fig. 1 D; Fig. 3 F; Table 2). Plants with four, five, and six flowering shoots were quite rare (Table 2). In nature, usually occur plants with one-three flowering shoots, sometimes - with five or six flowering shoots (Trotner, 2017). Although, Litvinenko (2010) reported that generative individuals of $\mathrm{G}$. odessanum in natural conditions could form up to 12 flowering shoots.

According to our long-term observations (2001-2021), the individuals of G. odessanum in the introduction conditions can persist in the generative state for over twenty years. Litvinenko (2010) indicated that the ontogenesis of G. odessanum typically lasts about 30 years, and the plants spend most of their life in a mature generative state. Thus, all individuals in the introduction coenopopulation of this species at the NBG today are direct descendants of initially introduced plants. 
Table 2. The number of generative individuals of Gymnospermium odessanum with a different number of flowering shoots in 2019-2021.

\begin{tabular}{llll}
\hline $\begin{array}{l}\text { Number of } \\
\text { flowering shoots } \\
\text { per plant }\end{array}$ & \multicolumn{3}{l}{ Generative individuals, number /\% } \\
\cline { 2 - 4 } & 2019 & 2020 & 2021 \\
\hline 1 & $32 / 78.0$ & $32 / 76.2$ & $34 / 75.6$ \\
2 & $4 / 9.8$ & $5 / 11.9$ & $5 / 11.1$ \\
3 & $4 / 9.8$ & $3 / 7.1$ & $4 / 8.9$ \\
4 & $0 / 0$ & $1 / 2.4$ & $1 / 2.2$ \\
5 & $1 / 2.4$ & $1 / 2.4$ & $0 / 0$ \\
6 & $0 / 0$ & $0 / 0$ & $1 / 2.2$ \\
Total & $41 / 100$ & $42 / 100$ & $45 / 100$ \\
\hline
\end{tabular}

\section{Age structure}

In the spectra of age states, the percentage of pregenerative individuals (i.e., seedling, juvenile, immature, and virginal) in 20192021 was very high $(89.5 \%$ in $2019,89.2 \%$ in 2020 , and $88.8 \%$ in 2021). For this period, the percentage of generative individuals was low (10.0\% in $2019,10.3 \%$ in 2020 , and $10.9 \%$ in 2021). The percentage of sub-senile individuals for this period was even much lower $(0.5 \%$ in $2019,0.5 \%$ in 2020 , and $0.3 \%$ in 2021; Fig. 4 ).

In previous years (2010-2017), the overall percentage of pregenerative individuals of ontogenesis was also very high (about 90\%), and the rate of generative individuals was low (about10 \%) (Gritsenko, 2010, 2014, 2017a).
Thus, the age structure of the introduction coenopopulation of G. odessanum is characterized by long-term stability.

In the natural populations of G. odessanum, there are present individuals of all age states (Scherbakova, 2005; Kritska \& Novosad, 2009; Scherbakova \& Novosad, 2018). The age spectra in the natural populations of this species are mostly left-sided, and only occasionally they are right-sided (Scherbakova, 2010; Scherbakova \& Novosad, 2018). In particular, in the natural coenopopulations of G. odessanum in the Ingulets river basin, the share of generative individuals was high (about $50 \%$ ), and age spectra were right-sided (Smetana et al. 2014). The age spectra of the introduction coenopopulation of G. odessanum at the NBG in 2010-2021 were left-sided, like in the most of natural populations.

\section{Spatial distribution and dissemination modes} The spatial distribution of particular individuals in the introduction coenopopulation of G. odessanum at the NBG is of two kinds - random and grouped. As a result of seed propagation and different dissemination modes, single individuals and groups of individuals of different age states occur within the same coenopopulation. Gymnospermium odessanum is a myrmecochorous plant (Litvinenko \& Shcherbakova, 2009; Scherbakova \& Barmak, 2013). Random distribution of its solitary individuals of different age states in the

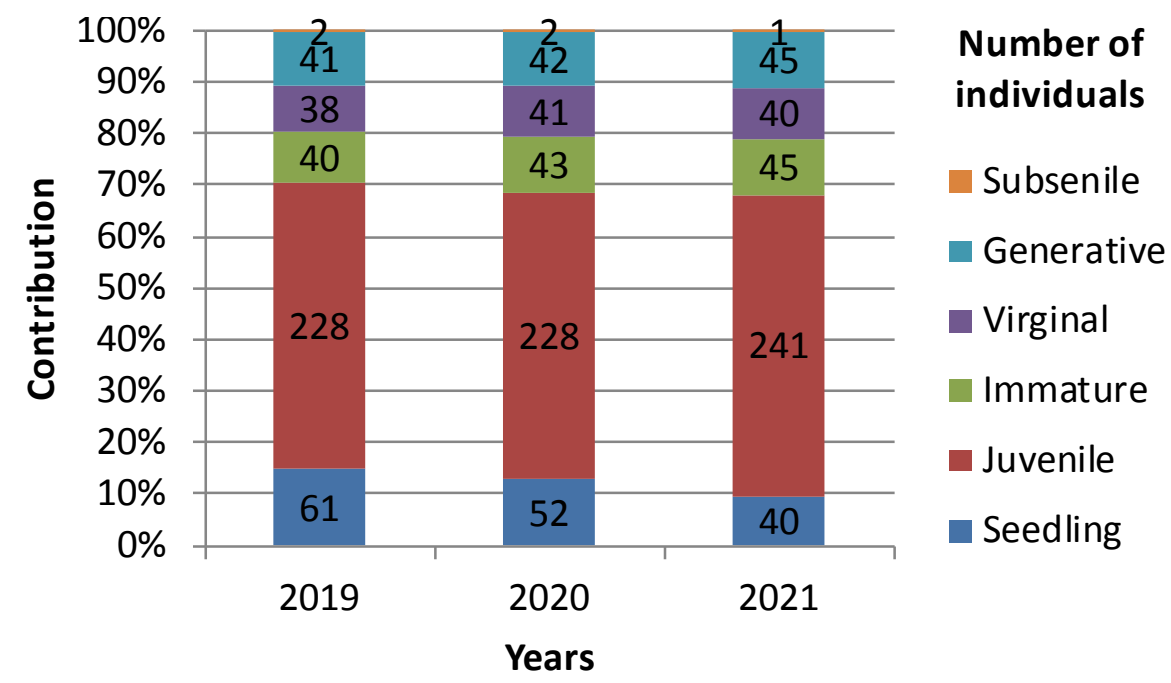

Figure 4. Age structure of Gymnospermium odessanum introduction coenopopulation at the NBG in 2019-2021. 

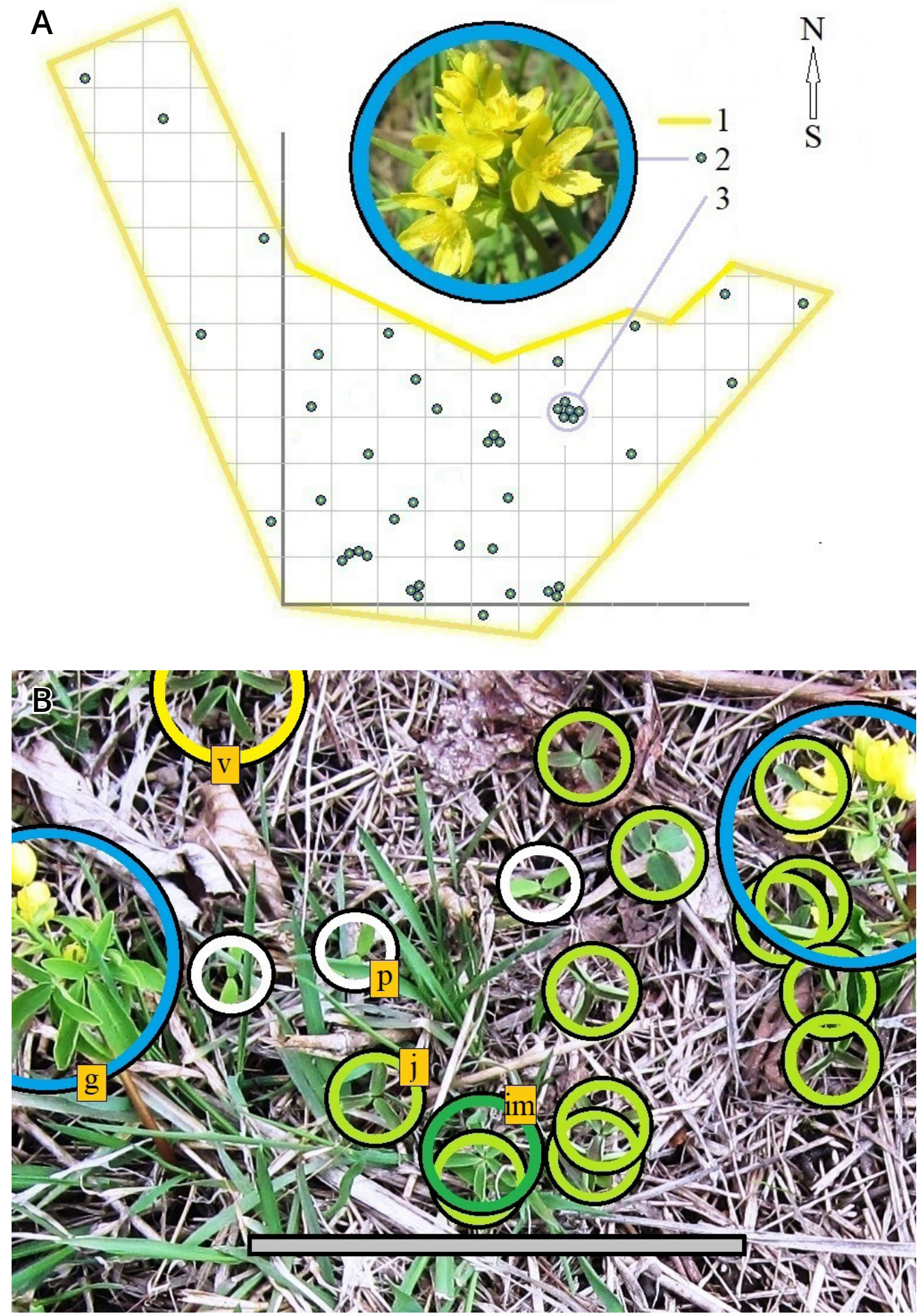

Figure 5. Spatial distribution of Gymnospermium odessanum individuals in the introduction coenopopulation at the NBG. A - boundaries of the coenopopulation (1), generative individuals in 2021 (2), and the fragment with the maximum density of generative individuals (3); scale $-50 \times 50 \mathrm{~m}$. $B$ - individuals of different age states, including seedling (p), and juvenile (j), immature (im), virginal $(\mathrm{v})$, and generative (g) plants; the circles indicate the phytogenic fields; scale $-10 \mathrm{~cm}$.

introduction coenopopulation may be a result of myrmecochory. The spatial distribution of generative individuals illustrates their bivariate (random and grouped) nature (Fig. 5 A). Many pregenerative individuals were located near the maternal generative individuals (Fig. 5 B), evidencing the barochory. Individuals of different age states differed in height. As a result, the leaf blades of adjacent individuals were located one above other, and formed a 
Table 3. The number of individuals of different age states in the introduction coenopopulation of Gymnospermium odessanum at the NBG in 2019-2021 (pairwise comparison).

\begin{tabular}{llllllllll}
\hline Age states & \multicolumn{2}{l}{$\begin{array}{l}\text { Number of } \\
\text { individuals, \% }\end{array}$} & \multicolumn{2}{l}{$\begin{array}{l}\text { Deviation, } \\
\text { \% }\end{array}$} & \multicolumn{2}{l}{$\begin{array}{l}\text { Number of } \\
\text { individuals, \% }\end{array}$} & $\begin{array}{l}\text { Deviation, } \\
\%\end{array}$ & $\begin{array}{l}\text { Number of } \\
\text { individuals, \% }\end{array}$ & $\begin{array}{l}\text { Deviation, } \\
\%\end{array}$ \\
\hline & 2019 & 2020 & & 2019 & 2021 & & 2020 & 2019 & \\
\hline Seedling & 14.9 & 12.8 & +14.09 & 14.9 & 9.7 & +34.90 & 12.8 & 14.9 & -16.41 \\
Juvenile & 55.7 & 55.9 & -0.36 & 55.7 & 58.5 & -5.03 & 55.9 & 55.7 & +0.36 \\
Immature & 9.6 & 10.5 & -9.38 & 9.6 & 10.9 & -13.54 & 10.5 & 9.6 & +8.57 \\
Virginal & 9.3 & 10.0 & -7.53 & 9.3 & 9.7 & -4.30 & 10.0 & 9.3 & +7.00 \\
Generative & 10.0 & 10.3 & -3.00 & 10.0 & 10.9 & -9.00 & 10.3 & 10.0 & +2.91 \\
Subsenile & 0.5 & 0.5 & 0.00 & 0.5 & 0.3 & +40.00 & 0.5 & 0.5 & 0.00 \\
\hline & 2020 & 2021 & & 2021 & 2019 & & 2021 & 2020 & \\
\hline Seedling & 12.8 & 9.7 & +24.22 & 9.7 & 14.9 & -53.61 & 9.7 & 12.8 & -31.96 \\
Juvenile & 55.9 & 58.5 & -4.65 & 58.5 & 55.7 & +4.79 & 58.5 & 55.9 & +4.44 \\
Immature & 10.5 & 10.9 & -3.81 & 10.9 & 9.6 & +11.93 & 10.9 & 10.5 & +3.67 \\
Virginal & 10.0 & 9.7 & +3.00 & 9.7 & 9.3 & +4.12 & 9.7 & 10.0 & -3.09 \\
Generative & 10.3 & 10.9 & -5.83 & 10.9 & 10.0 & +8.26 & 10.9 & 10.3 & +5.50 \\
Subsenile & 0.5 & 0.3 & +40.00 & 0.3 & 0.5 & -66.67 & 0.3 & 0.5 & -66.67 \\
\hline
\end{tabular}

vertical spatial pattern. Hence, phytogenic fields of individuals of different age states overlaped (Fig. 5 B).

\section{Number and density of individuals}

In 2019-2021, the total number and average density of $\mathrm{G}$. odessanum individuals did not change significantly. The total number of individuals of different age states was 410 in 2019, 408 - in 2020, and 412 - in 2021 (Fig. 4). The most abundant were juvenile individuals, while sub-senile ones were very rare (Fig. 4). The number of individuals of other age states (seedlings, immature, virginal, and generative individuals) was not large and was commensurate with each other (Fig. 4). The largest number of seedlings was observed in 2019, the smallest - in 2021 (Fig. 4).

The number of seedlings and subsenile individuals in the introduction coenopopulation at the NBG in 2019-2021 was characterized by the most extensive variation range. Simultaneously, juvenile, immature, virginal, and generative individuals demonstrated much lower variation ranges (Table 3).

Natural populations of G. odessanum predominantly consist of a pretty high number of individuals (Scherbakova, 2005). In particular, natural coenopopulations of this species in the basin of Ingulets river have from several tens to several hundreds of individuals (Smetana et al., 2014). Therefore, the number of individuals in the introduction coenopopulation of $G$. odessanum is significant compared with many natural coenopopulations.

Considering the density of individuals in the introduction coenopopulation of G. odessanum at the NBG, the following aspects were noted. In several different fragments of the coenopopulation, the density of individuals was high and reached up to 25 individuals per $1 \mathrm{~m}^{2}$ (Fig. $5 \mathrm{~B}$ ). At the same time, there were many fragments within the coenopopulation with low density (from one to several individuals) or even zero presence. Hence, the average density of $G$. odessanum here was only 0.1975 individuals per $1 \mathrm{~m}^{2}$ in 2019, 0.1966 individuals per $1 \mathrm{~m}^{2}$ in 2020, and 0.1985 individuals per $1 \mathrm{~m}^{2}$ in 2021. Considering that fragments with a high density of G. odessanum individuals are rather rare, its average density within coenopopulation is relatively low.

Trotner (2017) also observed uneven distribution of $\mathrm{G}$. odessanum individuals in natural conditions. However, the density was high for most part of the population. Natural populations of G. odessanum are generally characterized by high density 
(Scherbakova, 2005) and comprise several dozen individuals per $1 \mathrm{~m}^{2}$ (Kritska \& Novosad, 2009). Thus, Shiryaeva et al. (2020) reported 15-25 individuals per $1 \mathrm{~m}^{2}$. Krasova et al. (2016) counted up to 170 individuals of the species per $1 \mathrm{~m}^{2}$ and registered its high projective cover. Similarly, Smetana et al. (2014) indicated from 1 to $44 \mathrm{G}$. odessanum plants per $0.25 \mathrm{~m}^{2}$ for 27 natural habitats. Scherbakova \& Novosad (2018) also noted the high number and density of G. odessanum individuals under conditions of ecological-coenotic optimum. Of course, the NBG conditions are far from such optimum.

\section{Development trends of introduction coenopopulation}

Gymnospermium odessanum on the botanicalgeographical plot "Steppes of Ukraine" successfully reproduces and settles for decades. Introduction coenopopulation of G. odessanum here is steady in time (longterm existence) and space (occupy the stable area). In this coenopopulation, the species demonstrates a constant tendency to preserve its stable position in the meadow-steppe cultural phytocoenosis and, probably, to further area extension due to myrmecochory.

\section{Conclusions}

Ecological and coenotic conditions at the NBG differ from those in the natural habitats of G. odessanum and are not optimal for this species. It grows here on the botanicalgeographical plot "Steppes of Ukraine" in the composition of artificially created meadow-steppe phytocoenosis. However, Gymnospermium odessanum demonstrated high eco-coenotic plasticity and, over the decades, has formed a homeostatic introduction coenopopulation here. Today all contemporary G. odessanum individuals in the introduction coenopopulation at the NBG are descendants of the initially introduced plants.

As of 2021, the area of introduction coenopopulation at the NBG was $2,075 \mathrm{~m}^{2}$. It consisted of 412 individuals (40 seedlings, 241 juvenile, 45 immature, 40 virginal, 45 generative, and one sub-senile plants). Fragments with a high density of individuals were rare, so the average density was low, with only about 0.2 individuals per $1 \mathrm{~m}^{2}$. In 2021, in the spectrum of age states, the total rate of pregenerative individuals of ontogenesis was high and amounted to $88.8 \%$, while the share of generative individuals was $10.9 \%$. In general, the age structure of this introduction coenopopulation is characterized by long-term (2010-2021) stability. Due to myrmecochoric and barochoric propagation, the spatial distribution of individuals in this introduction coenopopulation is uneven and of two kinds - random and in groups.

Compared to natural populations, the investigated introduction coenopopulation of G. odessanum is characterized by a large area, significant number, and low average density of individuals. Like in most natural populations, the age spectrum in this introduction coenopopulation is left-sided.

The conducted research testifies the successful formation of the introduction coenopopulation of $G$. odessanum in the meadow-steppe cultural phytocoenosis of the NBG. This introduction coenopopulation is an example of successful multi-decade scientific experiment and effective ex situ protection and preservation of $G$. odessanum on the northern border of the Right Bank Forest-Steppe of Ukraine, far beyond its natural range.

\section{References}

Barina, Z., Caković, D., Pifkó, D., Schönswetter, P., Somogyi, G., Frajman B. (2017). Phylogenetic relationships, biogeography and taxonomic revision of European taxa of Gymnospermium (Berberidaceae). Botanical Journal of the Linnean Society, 184(3), 298-311. https://doi.org/10.1093/ botlinnean/box028

Beideman, I. N. (1974). Methods for studying the phenology of plants and plant communities. Nauka. (In Russian)

Borodina, R. M. (1972). Introduction of plants of the Ukrainian steppes. In S. S. Kharchenko (Ed.), Introduction of useful plants of natural flora of the USSR in Ukraine (pp. 40-68). Naukova Dumka. (In Ukrainian)

Borodina, R. M. (1976). Biological features of Gymnospermium odessanum (DC). Takht. in the conditions of CRBG of the Academy of Sciences of the UkrSSR. Introduction and acclimatization of plants in Ukraine, 8, 151-154. (In Ukrainian)

Doroftei, M., \& Mierla, M. (2007). Gymnospermium altaicum in northern Dobrogea. Brukenthal Acta Musei, 3(1), 6-12. https://www.academia. edu/22593995/GYMNOSPERMIUM_ALTAICUM_ IN_NORTHERN_DOBROGEA_Preliminary_Data 
Euro+Med PlantBase. (2021). The information resource for Euro-Mediterranean plant diversity. https://www.emplantbase.org/home.html

Gaponenko, M. B., \& Gnatiuk, A. M. (2016). Formation of introduction population of plants as a way for conservation the rarity flora fund. Bulletin of the Botanical Garden-Institute, 15, 13-15. (In Russian). https://botsad.ru/media/ cms/3615/13-15.pdf

Google Maps. (2021). https://www.google.com. ua/maps/@50.4122646,30.5646912,295m/ data=!3m1! $1 \mathrm{e} 3$ ?hl=ru

Gritsenko, V.V.(2009). The results of the introduction of plants in the botanical-geographic plot "Steppes of Ukraine" in M.M. Gryshko National Botanical Gardens of the NAS of Ukraine. Plant Introduction, 44, 18-24. (In Ukrainian). https://doi. org/10.5281/zenodo.2555365

Gritsenko, V. V. (2010, October 11-15). Rare species of spring ephemeroids on the botanicalgeographical plot "Steppes of Ukraine" at the M.M. Gryshko National Botanical Garden of the NAS of Ukraine. In Proceedings of the International Conference "Flora in the Red Data Book of Ukraine: implementation of the global strategy for plant conservation" (pp. 250-252). Alterpress. (In Ukrainian)

Gritsenko,V.V.(2012). Rarespecies of plants in steppe culturphytocoenose: the systematic composition, sozological characteristic, the historical aspects of the introduction, the contemporary state. Plant Introduction, 54, 13-21. (In Ukrainian). https://doi. org/10.5281/zenodo.2541996

Gritsenko, V. V. (2014). Introduced cenopopulations of the rare species of plants, brought in the Red Data Book of Ukraine, in steppe culturphytocoenose. Florology and Phytosozology, 3-4, 276-281. (In Ukrainian)

Gritsenko, V. V. (2017a, March 14-15). Experience of conservation and ex situ protection of plant species, listed in the Red Book of Ukraine, in the M.M. Gryshko National Botanical Garden, National Academy of Sciences of Ukraine on botanical-geographical plot "Steppes of Ukraine". In Proceedings of the All-Ukrainian scientific-practical conference "Affair of reserve in the Steppe zone of Ukraine". Series "Conservation Biology in Ukraine", Vol. 2(2) (pp. 60-65). (In Ukrainian). http://uncg. org.ua/wp-content/uploads/2019/04/UNCG22Nadmorsky_T2.pdf

Gritsenko, V. V. (2017b). Phytodiversity of the botanical-geographical section "Steppes of Ukraine" in the National Botanical Garden N.N. Grishko NAS of Ukraine. Forestry and Gardening, 12, 9558. (In Ukrainian). http:// journals.nubip.edu.ua/index.php/Lis/article/ view/9558/
Gritsenko, V. V. (2019a). Evaluation of success of introduction of rare species of plants in the meadow-steppe culturphytocoenosis. Plant Introduction, 82, 24-33. (In Ukrainian). https://doi. org/10.5281/zenodo.3241019

Gritsenko, V. V. (2019b). Model of the meadow steppe of Ukraine: The plant and animal world. News of the Biosphere Reserve Askania Nova, 21, 308-318. (In Ukrainian). http://askanianova-zapovidnik.gov.ua/2020/02/21/vistibiosfernogo-zapovidnika-askaniya-nova-2019/

Gritsenko, V. V. (2020). Formation of the introduced coenopopulation of Crocus reticulatus on the botanical-geographical plot "Steppes zzof Ukraine" at the M.M. Gryshko National Botanical Garden of the NAS of Ukraine. Plant Introduction, 87/88, 65-75. https://doi.org/10.46341/ PI2020036

Gritsenko, V. V. (2021, September 28-30). Phenology of Gymnospermium odessanum (DC.) Takht. in the M.M. Gryshko National Botanical Garden of NAS of Ukraine. Journal of Native and Alien Plant Studies, 17, 58-63. (In Ukrainian). https:// doi.org/10.37555/2707-3114.1.2021.247365

Gritsenko, V. V., Gnatiuk, A. N., \& Kushnir, N. V. (2017, June 6-8). The results of the introduction of rare species of steppe ephemeroids to the National Botanical garden of Ukraine. In Proceedings of the International Conference "Role of Botanical Gardens and Arboretums in conservation, investigation and sustainable using diversity of the plant world" dedicated to 85-th anniversary of the Central Botanical Garden of the NAS Belarus. Part 1 (pp. 63-66). Minsk. (In Russian). http://hbc.basnet.by/hbcinfo/books/ConfMinsk2017-part1.pdf

Izverskaya, T. D., Gendov, V. S., \& Syrodoyev, G. N. (2017). A critically endangered species of vascular flora of the Dniester river basin in Moldova: prediction of behavior in new climatic condition. Advances in Modern Science, 2(9), 101-108. (In Russian). https://elibrary.ru/item. asp?id=29905683

Izverskaya, T., Gendov, V., \& Shabanova, G. (2013, September 27). Rare forest species in the Republic of Moldova. Horticultură, viticultură şi vinificaţie, Silvicultură şi grădini publice, Protecţia plantelor, 36(2), 21-25. (In Russian). https://ibn. idsi.md/sites/default/files/imag_file/21-25_13. pdf

Kolomiychuk, V. P., \& Popova, O. M. (2018). The new concept of biota protection oin the Republic of Moldova. The Red Data Book of Moldova (2015). Review. Chornomorski Botanical Journal, 14(1), 98-100. http://cb-journal.net/wp-content/ uploads/2018/07/10.pdf

Krasova, O.O., Scholl, G. N., \& Baranets, M. O. (2019). Finds of plants listed in the Red Book of Ukraine 
in the Right Bank steppe. In A. A. Kuzemko (Ed.), Finds of plants and fungi of the Red Book and the Berne Convention (Resolution 6). Vol. 1 (pp. 252260). Print Art. (In Ukrainian). http://uncg.org. ua/wp-content/uploads/2019/05/roslyny-chkutom1s.pdf\#page $=253$

Krasova, O. O., Smetana, O. M., Dolina, O. O., Golovenko, E. A., Taran, Y. V., \& Pavlenko, A. O. (2016). Preservation of rare ephemeroids in technogenic biocenters of Kryvbas. In M. V. Grin'ova (Ed.), Proceedings of the AllUkrainian scientific-practical conference "Problems of reproduction and protection of biodiversity of Ukraine" (pp. 87-90). Astraya. (In Ukrainian). http:// dspace.pnpu.edu.ua/handle/123456789/13256

Kritska, L. I. (2012, October 9-12). Gymnospermium odessanum (DC.) Takht.: taxonomic, geographical and florogenesis aspects. In Proceedings of II International Conference "The plant kingdom in the Red Data Book of Ukraine: implementing the global strategy for plant conservation" (pp. 123-126). Publisher Palyvoda A.V. (In Ukrainian). http:// www.botany.kiev.ua/doc/konf_kr_kn_2012.pdf

Kritska, L. I., \& Novosad, V.V. (2009). Gymnospermium odessanum (DC.) Takht. In Y. P. Didukh (Ed.), Red Book of Ukraine. Plant Kingdom (p. 341). Globalconsulting. (In Ukrainian). https:// redbook-flora.land.kiev.ua/341.html

Krokhmal, I., \& Netsvetov, M. (2015). Phenology and population structure of forest herbaceous species in artificial and natural communities in the steppe zone of Ukraine. Acta Biologica Universitatis Daugavpiliensis, 15(1), 113-127. http://sciences.Iv/wp-content/uploads/2016/02/ Krokhmal.pdf

Litvinenko, O. I. (1986). Peculiarities of shoot formation of the Odessa leontitsa. Bulletin of the Moscow Society of Nature Experts, department of Biology, 91(4), 53-56. (In Russian)

Litvinenko, O. I. (2010). Biomorphological determination of Gymnospermium odessanum (DC.) Takch. as an ephemeric geophyte. Chornomorski Botanical Journal, 6(3), 352-364. (In Ukrainian). http://cbj.kspu.edu/images/ PDF/1/2010_3/cbj352364.pdf

Litvinenko, O. I., \& Shcherbakova, O. F. (2009). Biomorph monocentricity as an ethological factor of the rare plants fund of Southern Ukraine. Pryrodnychyi Almanakh, Series Biological Sciences, 12, 166-172. (In Ukrainian). http:// na.kspu.edu/index.php/na/article/view/298

Mashkovska, S. P. (Ed.). (2015). Catalog of ornamental herbaceous plants of botanical gardens and arboretums of Ukraine: a reference guide. Kyiv. (In Ukrainian). http://www.nbg.kiev.ua/upload/ biblio/katalog.pdf
Melnyk, V.I. (1994). Area, habitat and age structure of the Gymnospermium odessanum (Berberidaceae) populations. Botanicheskii Zhurnal, 79(7), 55-61. (In Russian).

Melnyk, V.I. (2000). Rare species offlora of the Ukrainian plain forests. Phytosociocenter. (In Russian)

Melnyk, V. I., Gritsenko, V. V., Kushnir, N. V., \& Nehrash, Y. M. (2018). Modeling of introduction populations as a method of exsitu protection of rare species of plants. Reports of the National Academy of Sciences of Ukraine, 8, 91-97. (In Ukrainian). https:// doi.org/10.15407/dopovidi2018.08.091

Pavlenko, A. O., Krasova, O. O., Korshykov, I. I., \& Baranets, M. O. (2020). Sozophytes in postmining landscapes of Kryvyi Rih basin. Bulletin of Odessa National University. Biology, 25(1), 23-41. (In Ukrainian). https://doi.org/10.18524/20771746.2020.1(46).205802

Peregrym, M. M., Bezsmertna, O. O., \& Erysova A. V. (2014). Species from the Red Data Book of Ukraine in "Rare and endangered plants of the natural flora of Ukraine" collection of the O.V. Fomin Botanical Garden. Chornomorski Botanical Journal, 10(1), 120-126. (In Ukrainian)

Ponomareva, A. A., Naumovych, A. A., Dzerkal, V. M., \& Zagorodnyuk, N. V. (2019). Projected botanic reserve "Bilgirskiy" (Kherson region, Ukraine). Pryrodnychyi Almanakh, Series: Biological Sciences, 26, 132-139. (In Ukrainian). https://doi.org/10.32999/ ksu2524-0838/2019-26-13

Prokudin, Y. N. (Ed.). (1987). Key to higher plants of Ukraine. Naukova Dumka. (In Russian)

Rosati, L., Coppi, A., Farris, E., Fascetti, S., Becca, G. Peregrym, M., Tan, K. \& Selvi, F. (2018). The genus Gymnospermium (Berberidaceae) in Italy: identity and relationships of the populations at the western limit of the genus range. Plant Biosystems, 153(6), 796-808. https://doi.org/10.1080/11263504.2018.1549613

Scherbakova, O. F. (2005, September 6-9). The current state of populations of Gymnospermium odessanum (DC.) Takht. on the northern border of the range and the problems of their protection. In Materials of the International Conference of Young Botanists "Actual problems of research and conservation of phytodiversity" (pp. 75-76). Phytosociocenter. (In Ukrainian)

Scherbakova, O. F. (2008). Rare flora component of Kodymo-Elanetsky Bug region (population and sozological aspects) [Candidate dissertation, Kyiv]. (In Ukrainian)

Scherbakova, O. F. (2010). Assessment strategies for behavior model rare plants species of Kodymo-Elanetsky Bug region. Proceedings of the National Museum of Natural History, 8, 129134. (In Ukrainian). http://dspace.nbuv.gov.ua/ handle/123456789/30351 
Scherbakova, O. F. (2011). Biomorphological analysis rare component flora of KodymoElanetsky Bug region. Proceedings of the National Museum of Natural History, 9, 11-30. (In Ukrainian)

Scherbakova, O. F., \& Barmak, I. M. (2013). Principles and approaches to the sozology categorization of rare plant species. Issues of Bioindication and Ecology, 18(1), 101-115. (In Ukrainian). http://sites.znu.edu. ua/bioindication/issues/2013-18-1/Scher.pdf

Scherbakova, O. F., \& Novosad, V. V. (2018, June 25-28). Chorological, ecological-coenotic and sociological features of Gymnospermium odessanum (DC.) Takht. In Proceedings of the 5th International Conference "The plant kingdom in the Red Data Book of Ukraine: implementing the global strategy for plant conservation" (pp. 98-101). Publisher Vyshemyrskyi V.S. (In Ukrainian). http:// www.terreco.univ.kiev.ua/_media/library/rare-plant/ parnikoza-celka-ophioglossaceae_2018.pdf

Shiryaeva, D. V., Kuzemko, A. A., \& Kolomiets, G. V. (2020). Monitoring studies in the context of forecasting the impact of raising the level of the Alexander Reservoir on rare species of flora and habitats of the Southern Bug Valley. In Monitoring and protection of biodiversity in Ukraine: flora and fungi. Vol. 1 (pp. 257-262). Print Art. (In Ukrainian)

Shiryaeva, D., Vinokurov, D., Kolomiets, A., \& Artamonov, V. (2019). Finds of plants listed in the Red Book of Ukraine in the territory of the National Natural Park "Buzky Gard" and adjacent areas. In A. A. Kuzemko (Ed.), Finds of plants and fungi of the Red Book and the Berne Convention (Resolution 6), Vol. 1 (pp. 448-456). Print Art. (In Ukrainian)

Smetana, O. M., Krasova, O. O., Dolyna, O. O., Taran, Y.V., \& Korzhov D. M. (2014). Characteristics of Gymnospermium odessanum (DC.) Takht. habitats in Ingulets basin. Nature Conservation, 1(20), 55-59. (In Ukrainian)

Sobko, V. G., \& Borodina, R. M. (1987). Age features of Leontitsa of Odessa in the conditions of culture. In Materials of the session of the Academic Council on Biological Problems of the Academy of Sciences of the UkrSSR and the Southern Branch of the VASKhNIL "Genetic resources of plants and animals of the Ukrainian SSR: study, use, replenishment and conservation"(pp. 89-91). Kyiv. (In Ukrainian)
Sobko, V. G., \& Gaponenko, M. B. (1996). Introduction of rare and endangered plants of the flora of Ukraine. Naukova Dumka. (In Ukrainian)

Sobko, V. G., Lebeda, A. F., \& Gritsenko, V. V. (2013). Phytorarities of the steppe zone of Ukraine. Phytosociocenter. (In Ukrainian)

Solomakha, I. V. (2015). Sozological characteristic of vegetation of forests and shrubs of the Northern Black Sea region. Biological Bulletin of the Melitopol State Pedagogical University named after Bogdan Khmelnitsky, 5(3), 130-139. (In Ukrainian). http:// geobot.org.ua/files/publication/1485/12342573-1-sm.pdf

Trotner (Pryimachuk), v. V. (2016). Finds of rare plants in the Kryvyi Rig region. Issues of steppe forest science and forest recultivation of land, 45, 60-67. (In Ukrainian). https://doi.org/10.15421/441610

Trotner (Pryimachuk), V. V. (2017, March 1415). Odessa gymnosperm (Gymnospermium odessanum (DC.) Takht.) (Berberidaceae) in Dnipropetrovsk region. In Proceedings of the All-Ukrainian scientific-practical conference "Affair of reserve in the Steppe zone of Ukraine". Series "Conservation Biology in Ukraine", Vol. 2(2) (pp. 165-169). Kyiv. (In Ukrainian). https://uncg. org.ua/wp-content/uploads/2019/04/UNCG22Nadmorsky_T2.pdf

Uranov, A. A. (Ed.). (1976). Plant coenopopulations (basic concepts and structure). Nauka. (In Russian)

Visjulina, O. D. (1953). Family Barberry Berberidaceae Torr. et Gray. In M. V. Klokov \& O. D. Visjulina (Ed.), Flora of the UkrSSR, Vol. 5 (pp. 152-155). Edition of the Academy of Sciences of the UkrSSR. (In Ukrainian)

Yermolaieva, A. Y. (2010). The history of investigation of rare and endangered ephemeroid geophytes of the Odessa region. Bulletin of Odessa National University. Biology, 15(17), 91-102. (In Ukrainian). http://liber.onu. edu.ua/pdf/vest_biol_2010_15_17.pdf

Zaitsev, G. N. (1978). Phenology of herbaceous perennials. Nauka. (In Russian)

Сучасний стан інтродукційної ценопопуляції Gymnospermium odessanum на ботаніко-географічній ділянці “Степи України” Національного ботанічного саду імені М. М. Гришка НАН України

Вікторія Гриценко

Національний ботанічний сад імені М. М. Гришка НАН України, вул. Тімірязєвська, 1, Київ, 01014, Україна; gritsenkoviktoria@gmail.com 
Gymnospermium odessanum - це раритетний реліктовий ендемічний вид. Дослідження проведені під час цвітіння G. odessanum у 2019-2021 рр. на ботаніко-географічній ділянці “Степи України" Національного ботанічного саду імені М. М. Гришка НАН України (НБС). Еколого-ценотичні умови інтродукції у НБС відрізнялись від природних місцезростань і не були оптимальними. Зокрема, G. odessanum росте на ботаніко-географічній ділянці “Степи України" у складі штучно створеного лучно-степового фітоценозу. Втім, G. odessanum проявив еколого-ценотичну пластичність i, упродовж десятиліть, сформував тут стійку гомеостатичну інтродукційну ценопопуляцію. Станом на 2021 р. площа інтродукційної ценопопуляції цього виду становила 2075 м². У її складі налічувалось 412 особин G. odessanum (40 проростків, 241 ювенільних, 45 імматурних, 40 віргінільних, 45 генеративних та 1 субсенільна). Фрагменти з високою щільністю особин G. odessanum траплялися рідко, тому середня щільність була низькою і становила 0,2 особини на 1 м². У 2021 р. у спектрі вікових станів загальний відсоток особин прегенеративного періоду онтогенезу був дуже високим і становив 88,8 \%, а частка генеративних особин становила 10,9\%.

В цілому, вікова структура інтродукційної ценопопуляції G. odessanum характеризується тривалою (2010-2021 рр.) стабільністю. Просторовий розподіл особин в інтродукційній ценопопуляції випадковий та груповий. Це пов'язано з мірмекохорним і барохорним поширенням. Ценопопуляція має тенденцію до подальшого збільшення площі, що обумовлено мірмекохорією. У порівнянні з природними ценопопуляціями, інтродукційна ценопопуляція G. odessanum характеризується великою площею, значною кількістю та низькою середньою щільністю особин. Вікові спектри, як і у більшості природних популяцій, $є$ лівосторонніми.

Проведені дослідження свідчать про успішне формування інтродукційної ценопопуляції G. odessanum в лучно-степовому культур-фітоценозі НБС. Ця інтродукційна ценопопуляція $\epsilon$ вдалим багаторічним науковим експериментом та представляє собою приклад ефективної ех situ охорони та збереження G. odessanum на північній межі Правобережного Лісостепу України, далеко за межами природного ареалу цього ендемічного виду.

Ключові слова: Gymnospermium odessanum, раритетний ендемічний вид, інтродукційна ценопопуляція, стабільна вікова структура, охорона еx situ 